\title{
The Relationship of Learning Indonesian in the School Environment to Motivate Students
}

\section{Oleh : Revanda Yendra}

\author{
revandap94@gmail.com
}

The environment has a very important role for life. Learning environmental materials leads to learning that uses the environment as a learning resource. The environment can be used as a learning resource, by linking the material being taught with real-world situations, which is expected to be able to make a connection between the knowledge possessed and everyday life. Environmental Material in Indonesian Language Learning is very important and interrelated material, because by having a good understanding of environmental material, especially in Indonesian language learning, a student will have sensitivity and concern for their environment, especially the classroom environment in learning Indonesian.

Environmental problems are caused by careless and intensive human activities in natural areas to improve the quality of life. Environmental damage causes a series of problems with natural resources, climate, pollution, food, and the economy, resulting in an imbalance in the environment. One of the efforts to solve this sustainable environmental problem is to instill in the young generation the importance of protecting the environment from an early age. Small things such as not littering, using water as needed, and so on are the first steps that can be done in the school environment.

According to Muhibbin, the school environment is the state of the school in which to learn which also affects the level of learning success. The condition of the school building and its location, as well as the learning tools that also determine the learning success of the ideal student. Hamalik said that the school environment is an institution that organizes teaching and learning opportunities that must meet various requirements, including: students, teachers, educational programs, dormitories, facilities and facilities. Everything has been arranged and arranged according to certain patterns and systematics so as to enable learning and teaching activities to take place and be directed at the formation and development of students.

Environment-based learning aims to motivate students and participate in the school environment. Motivation is something that plays a role in the progress and development of students in the learning process. If the teacher's motivation is right on target it will increase 
learning activities. Clear goals make students study more diligently, more actively and enthusiastically. Motivation is an absolute prerequisite for learning. At school there are often children who are lazy, unpleasant, like to play truant and so on. In this case it means that the teacher does not succeed in providing the right motivation to encourage him to work with all his might and mind. Motivation is a force, both from within and from outside that encourages a person to achieve certain predetermined goals. Or in other words, motivation can be interpreted as a mental drive against individuals or people as members of society (Sumantri, 2015: 375).

Motivation to learn is one of the driving factors or contributions to the achievement of good Indonesian language learning, learning motivation also affects student learning outcomes, especially Indonesian learning outcomes because learning motivation can improve student learning outcomes. This is in accordance with research conducted by Ningsih (2013) which states that learning motivation plays a role and contributes to Indonesian learning outcomes.

Based on the problems described above, the authors conducted research on the importance of environmental materials in learning Indonesian in schools. The research was conducted by making 10 statements in the form of a google form questionnaire. The results obtained from this study are as follows. The first statement is the need for environmental material in Indonesian subjects to motivate students to learn to get results strongly agree $35.3 \%$ and $64.7 \%$ agree. The second statement is that environmental material plays an important role in learning Indonesian, getting results strongly agree $26.5 \%$, agree $73.5 \%$.

The third statement, namely Using the theme of the environment in learning to motivate students to learn Indonesian, get the results $79.4 \%$ strongly agree and $20.6 \%$ agree. The fourth statement is that teachers have an important role in teaching environmental education to students in order to motivate students in learning to get results. $52.9 \%$ strongly agree, and $47.1 \%$ agree.

The fifth statement is that the teacher prepares teaching materials about the environment to motivate students, getting results that $41.2 \%$ strongly agree, $55.9 \%$ agree and $2.9 \%$ disagree. The sixth statement, namely by studying the environment can motivate students' skills in writing explanatory text which get the results $26.5 \%$ strongly agree, and $73.5 \%$ agree. The seventh statement is that with the existence of environmental material 
students can be more active in learning Indonesian which gets $32.4 \%$ results strongly agree, $64.7 \%$ agree and disagree $2.9 \%$.

The eighth statement, namely Indonesian language learning material in a school environment is easier to convey to students, getting results $55.9 \%$ strongly agree, and $44.1 \%$ agree. The ninth statement, namely the material of the school environment to motivate students to learn more easily understand the Indonesian language material which got results $26.5 \%$ strongly agree, $67.6 \%$ agree and $5.9 \%$ disagree. The tenth statement, namely before starting the lesson the teacher asked students to look at the environment around which got results $26.5 \%$ strongly agreed, $70.6 \%$ agreed and $2.9 \%$ disagreed.

Based on the results of studies and research conducted by the author, it can be concluded that environmental material has an important role and is also related to Indonesian language learning to motivate students. Environmental insight education can be integrated into Indonesian subjects and subjects to provide comprehensive knowledge and skills in protecting the environment. Environmental material is material that is closely related to everyday life. Therefore, with environmental material the teacher can easily find relevant examples to make students understand more about the material provided, so that it can help teachers imply Indonesian language material in schools. Based on research conducted by the writer, the voice obtained shows that environmental material has a close relationship with Indonesian language learning to motivate students. 


\section{References :}

Ramadhan, S., Sukma, E., \& Indriyani, V. (2019). Environmental education and disaster mitigation through language learning. IOP Conference Series: Earth and Environmental Science, 314, pp. 1-9.

Bergman, B.G. (2016). Assessing impacts of locally designed environmental education projects onstudents' environmental attitudes, awareness, and intention to act Environmental EducationReseach 22(4) 480-503

Obasoro C B, Oyinloye O A and Ilensami A A 2013 The importance of environmental education to secondary education level in Akure South local goverment area, Ondo State Nigeria African Research Review 7(4) 298-306.

Hauchild, S., Poltavthenko, E. and Stoller, F. L. (2012). Going green: Menging environmental education and language instruction English Teaching Forum Number $22-13$ 